\title{
I.-Notes on some Remains of Chiton and Chitonellus from the Carboniferous Strata of Yorkshire and the West of SCOTLAND.
}

By Mrsses. James W. Krrkey and Johr Young.

(PLATE XVI.)

NINCE the occurrence of Chitons, in the Mountain Limestone of Settle, was noticed by one of us, in $1862,{ }^{1}$ other remains have been found in the same rock, as well as in the Carboniferous Limestone and shales of Scotland. The former were discovered, as before, by Mr. J. H. Burrow, of Settle, who has kindly placed them in our hands for description.

Both suites of remains are, as is usual with fossils belonging to this group of mollusca, in the state of isolated plates. Those from Yorkshire are from the Lower Scar Limestone, where they are found associated with great numbers of other fossils, such as Orthoceras Goldfussianum, De Kon. ; Goniatites striatus, Phillips ; Spirifera cuspidata, Rhynchonella angulata, etc., etc. Those from the West of Scotland are from the calcarenus shales of the Lower and Upper Limestone series of Craigenglen, Campsie; Williamwood, near Catheart, Renfrewshire; Braidwood, near Carluke ; and Robroystone, N.E. of Glasgow ; and they, like the Yorkshire specimens, occur associated with many other marine fossils.

The Scotch specimens do not appear to have been much worn or corroded before they were imbedded in the rock materials. The Yorkshire plates, on the contrary, are nearly all more or less injured in respect to surface. They are likewise thick-shelled compared with the Scotch species, and seem to have been adapted, as well as subjected, to the wear and tear of a rock-bound coast.

Desscription of Specimens from Yorkshire :-

1. Chiton Burrowianus, Kirkby, 1862. [Quart. Journ. Geol. Soc. vol. xviii. p. 234, figs. 1 and 2.] Plate XVI. Figs. 14 and 15.

This species was described from two plates, a posterior and an intermediate one. Other two have been found by $\mathrm{Mr}$. Burrow, which are likewise posterior and intermediate. The last found posterior is larger than the first, being an inch in width and five-eighths in length. It is much worn and does not show any additiunal feature. The intermediate plate has apparently belonged to a smaller individual and is not quite perfect.

2. Chiton coloratus, Kirkby, 1862. [Quart. Journ. Geol. Soc. vol. xviii. p. 234, figs. $3,4,5,6$.] Plate XVI. Figs. $8 a, 8 b$.

Several imperfectly preserved posterior plates occur. Also an anterior plate, which is very thick-shelled, and which has a worn surface that retains traces of granulation. The anterior margin forms rather more than a semi-cirele; the posterior is concave on each side of the apex, and projects backwards to join the anterior margin. Length three-eighths of an inch; width half an inch; height three-sixteenths of an inch.

3. Chiton Loftusianus, King, 1848. [Catalogue of Org. Rem. Perm. Foss. p. 12.] Plate XVI. Fig. 17.

In a former paper, ${ }^{2}$ by one of us, an intermediate plate of a Chiton is figured that greatly resembles those of C. Loftusianius, King, of the Magnesian Limestone. Its resemblance to that species was pointed out, though it was not identified with it.

Tuart. Journ, Geol. Soc. vol. xviii. p. 233.

2 Ibid, p. 236. 

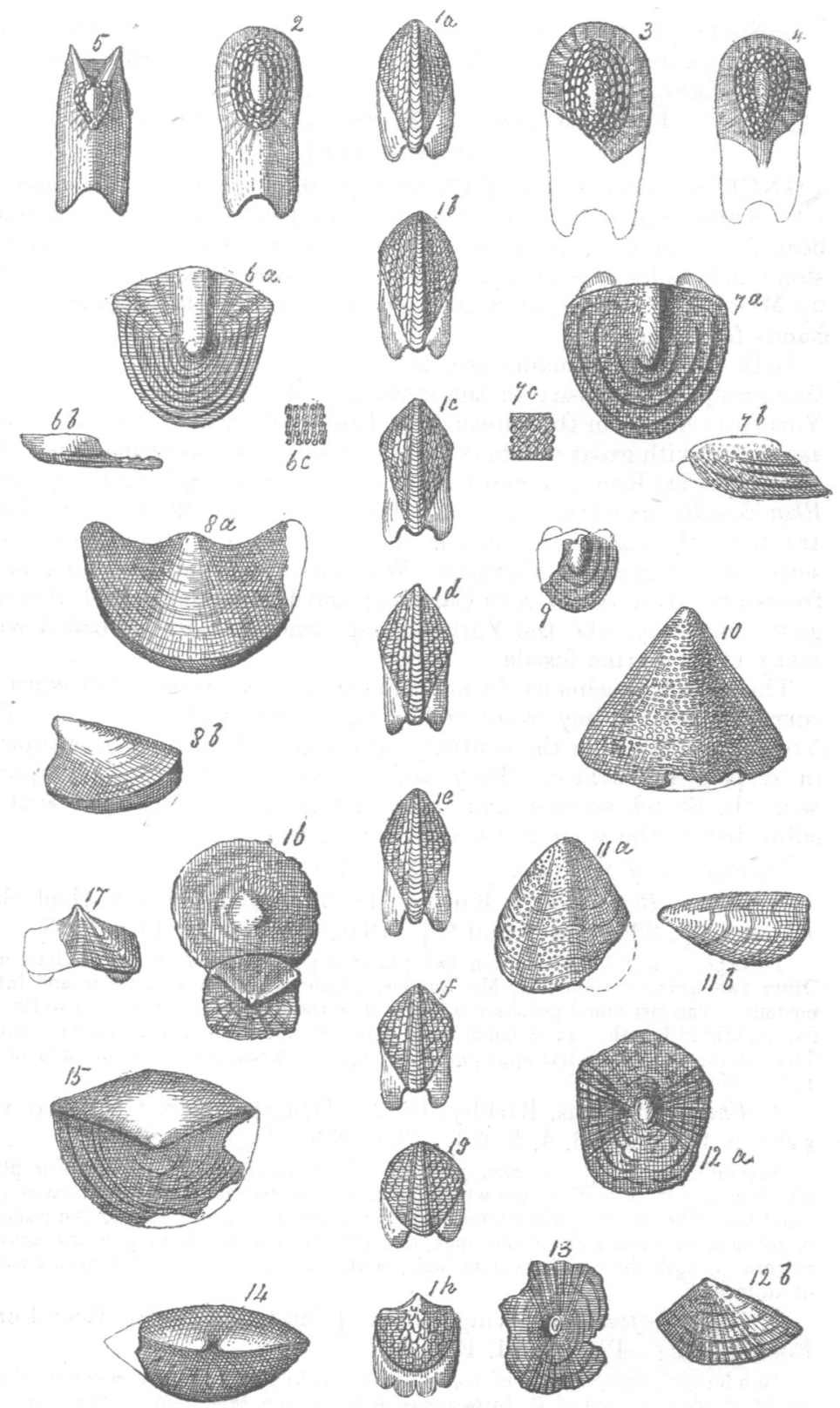

G. R. De Wilde, fecit. Hailes \& Co., Imp. RECENT \& CARBONIFEROUS CHITONIDE. 
Another plate of the same kind occurs among Mr. Burrow's recent discoveries, and we venture to identify both it and the former one with the last-named species.

4. Chiton (?) cordatus, Kirkby, 1859. [Quart. Journ. Geol. Soc., vol. xv. p. 616, pl. xvi., figs. 24, 27, 54.] Plate XVT. Figs. 10a, b, $11 a, b$.

An intermediate plate, and, I believe, an anterior one, occur among the Yorkshire specimens. Both are larger than the Permian specimens from which the species was doseribed.

The intermediate plate is almost cordate in shape, being comparatively broad, rounded, and centrally sinuated anteriorly, and extremely narrow and acuminate posteriorly, - the anterior, lateral, and posterior margins blending insensibly together. The median line is slightly arched; the lateral areas occupy less than two-thirds of the plate-surface, and are separated from the dorsal area by a slight sulcus. The surface is finely granulated; length, half an inch, and the same in breadth.

The anterior plate is semi-cone shaped; is over half an inch wide, three-eighths of an inch high, and a quarter of an inch long. It is thick-shelled, and has the surface covered with rather coarse, oval granulations, regularly arranged in concentric lines.

Both these plates closely resemble the type specimens of $C$. cordatus, except in the granulated surface of the anterior plate, which differs both from the intermediate plate we describe here and from the Permian specimens. It may possibly belong to another species, but as it comes so close to C. cordatus in other characters, we place it along with that species for the time being.

5. Chitonellus (?) subantiquus; sp. nov. Plate XVI. Figs. 12a, b, 13.

We describe two patelliform plates under this genus, as we consider them to be plates of Chitonellus, though as the marginal processes of insertion are not exposed, our opinion as to their generic position can scarcely be free from donbt. They evidently belong either to that genus or to one of the groups of Patelliform Gasteropoda, though we believe to the former. Indeed, one plate so nearly approaches the Permian species $C$. antiquus, Howse (see fig. 17, pl. svi. Quart. Journ. Geol. Soc.), as to render its separation from it a matter of difficulty. The following is a brief description of the most perfeet plate, which we take to be an intermediate one.

Conical, sub-pentagonal in marginal outline, apex recurved and placed rather behind the centre of the plate. Several fine ribs radiate from the apex down each side, and others appear to have originally existed in front and behind, but are not now visible on this specimen, owing to the imperfect preservation of the shell in these parts. Surface marked with strong lines of growth; length rather under threeeighths of an inch; breadth rather over two-eighths of an inch.

Description of Scotch Specimens :-

1. Chiton humilis, Kirkby, 1865. [Trans. Geol. Soc., Glasgow, vol. ii. p. 14, pl. i., fig. 1.] Plate XVI. Figs. $6 a, b, c$.

This species was discovered two years ago and described in the Transactions of the Geological Society of Glasgow. The only perfect plate found is a posterior one, which we re-figure. It occurs in calcareous shale in the Robroystone beds N.E. of Glasgow.

2. Chiton sp. Plate XVI. Figs. $7 a, b, c, 9$.

Mr. Jas. Armastrong and Mr. Jas. Bennie, of Glasgow, have found three posterior plates in the Carboniferous Limestone Shale of Williamwood, near Cathcart, in Renfrewshire, which differs from the preceding species. They are relatively broader, more pointed in front, and more sharply angulate, and with coarser surface granulations than the equivalent plate of $C$. humilis. They are about one-fifth of an inch wide, and the same or a little less in breadth, and show well-developed processes of insertion.

These plates approach nearest to Chiton Burrowianus of any Chiton known to us; but they do nor come near enough to allow them to be identified with that species. We leave them for the present unnamed.

3. Chitonellus Youngianus, Kirkby, 1865. [Trans. Geol. Soc., Glasgow, vol. ii. p. 14, pl. i., fig. 2.] Plate XVI. Figs. 2, 3, 4.

Since the discovery of a single plate of this species in 1865, portions of two others have been found. These we figure along with the first. 
The plates discovered appear to be intermediate ones. The one that is perfect is ninethirty-seconds of an inch long and four-thirty-seconds of an inch broad. It is ovately oblong in outline, with an anterior sinus, and is sharply ridged along the median line from the apex forwards. The apex is placed about one-fifth from the anterior margin. The exposed portion of the plate, or that which was uncovered by the mantle, is slightly raised, anteriorly, ovate in shape, and with a pustulous surface; the inserted portion of the plate is marked with coarse, radiating striæ, except in front.

The other two plates are both imperfect in the anterior inserted portion; but so far as they are preserved, they both agree precisely with the one described. They were found in the marine shales of Craigenglen. Another perfect plate appears to have been found by the late Mr. Alex. Cowan of Campsie, but has been lost.

All the plates have been found in the marine shales of Craigenglen, Campsie.

4. Chitonellus subquadratus, sp. nov. Plate XVI. Fig. 5.

We designate by the above name another plate that has also occurred in the Craigenglen shales, and which cannot be referred to $C$. Youngianus. It may be described as subquadrate in outline," with both anterior and posterior margins forked, but with the former more so than the latter, and with the anterior portion of the plates rather narrower than the other. It is ridged or angular along the median line from the apex forwards; and from near the apex posteriorly two declining angular ridges diverge and run into two sharp projections that are formed by the junction of the latero-posterior margins. The exposed portion of the plate is very small compared with the portion that was buried in the animal, being not more than a fifth or sixth part; it is heart-shaped, with the pointed extremity in front; it is slightly elevated above the rest of the plate, and granulated about the margin. Numerous delicate stria fringe this heart-shaped area on the surface of the inserted portion of the plate. Length, quarter of an inch; breadth, one-eighth of an inch.

Besides the species which we have already enumerated from Scotland, Mr. John Hunter, of Braidwood, near Carluke, has obtained from the main limestone of that place one or two small plates of a species of Chiton, which we have been unable to determine correctly, owing to their imperfect preservation.

Mr. James Thomson, of Glasgow, has also a Chiton plate in his collection, from Carboniferous shale on the banks of the Anan, near Strathanan. His specimen, so far as we remember, agrees very closely in form and ornamentation with the Chiton gemmatus of De Koninck.

It is not unlikely, when the affinities of the palæozoic Chitonida can be carefully investigated, that the generic nomenclature adopted at present will require revision and alteration. Some of the species described would almost appear to possess points of more than specific difference from all the known recent types of Chiton, so that it may ultimately be found requisite to establish new genera for their reception. It is well, however, not to be too hasty in the formation of new types; for our knowledge of the palæozoic species is nearly in every case imperfect, and in some instances the conclusions drawn from the facts known may be erroneous.

We give figures of the eight plates of the recent Chitonellus striatus, Lam., to illustrate the nearer approach of the fossils we describe as Chitonelli to that genus than to Chiton. From these it will be seen that in Chitonellus the plates are longer than broad, while in Chiton just the contrary holds; also that the plates are not formed to imbricate on each other as in Chiton, but to be fixed isolatedly, though firmly, in the mantle; and, lastly, that much more of the plate is inserted in or covered by the mantle of the mollusc. In these 
respects the fossil species to which we allude certainly approach nearer to Chitonellus than to Chiton.

\section{EXPLANATION OF PLATE XVI.}

Figs. Ia, $b, c, d, e, f, g, h$. Ohitonellus striatus, Lamarck. Recent, from the coast of New Holland. The plates are detached from the mantle; fig. $1 a$ being the anterior, and $1 h$ the posterior. Magnified three times.

Figs. 2, 3, 4. Chitonellus Youngianus, Kirkby. Intermediate plates. Magnified three times. From Craigenglen, Campsie.

Fig. 5. Chitontellus subquadratus, sp. nov. Intermediate plate. Magnified three tines. Craigenglen, Campsie.

Figs. $6 a, b, c$. Chiton humilus, Kirkby. Posterior plate, magnified; $b$ lateral view ; portion of granulated surface highly magnified. Robroystone.

Figs. $7 a, b, c, 9$. Chiton $s p$. Posterior plates; $7 b$ lateral view; $7 c$ portion of surface highly magnified. Williamwood, near Catheart.

Figs. $8 a, b$. Chiton coloratus, Kirkby. Anterior plate, magnified; $b$ lateral view. Settle.

Figs. 10, 11a,b. Chiton (?) cordatus, Kirkby. 10, anterior plate; $11 a$, intermediate plate ; $b$ lateral view of same. Magnified. Settle.

Figs. 12a, $b, 13$. Chitonellus subantiquus, sp. nov. Intermediate plates; $12 b$, lateral view. Magnified. Settle.

Figs. 14, 16. Chiton Burrowianus, Kirkby. Posterior plates, one (14) being distorted by pressure. Settle.

Fig. 16. Chitor, sp. indet. Settle.

Fig. 17. Chiton Loftusianus, King. Intermediate plate. Settle

\section{III.-Kitchen-Middens on the Gritat Ormkeshead.}

By the Rev. T. G. Bonnry,;M.A., F.G.S.

T CAME accidently upon the deposits which are the subject of 1 this brief notice, the afternoon before I left Llandudno last April. Want of time prevented my making more than a hasty examination of them, but I think that they will repay any one who happens to be visiting Llandudno this summer, and will devote a day or two to them.

After passing the Dean of Christchurch's house, a gate leads on to the shore of Conway Bay (Pen-morfa on the Ordnance Map.) A high steep talus covered with thin turf, here separates the fine limestone cliffs of the Ormeshead from the shore, the lower part of which has been eaten away by the waves, so that a cliff has been formed, which soon rises to a height of some twenty feet; the lower tier of limestone soon emerges from the shingle and slopes upwards, still separated from the upper cliff by the drift-covered talus. The deposits of which I have to speak occur between the above-named gate and the place where the lower limestone makes its appearance. Directly after passing through the gate, we find a thin seam of Mytilus edulis with Balanus balanoides attached to the shells, and a sort of bed, or pocket, of Mytili $1 \frac{1}{2}$ feet below it. These perhaps may not be the remains of a Midden, but of a mussel-bed corresponding with those along the same shore about a mile to the south.

The cliff rises rapidly, and about four or five yards further on to the N.W., we have a tolerably clear face with the following section :

(1) Soil with angular fragments of limestone, $1 \frac{1}{2} \mathrm{ft}$.

(2) A very thin seam of shells mostly Littorina littorea.

(3) Dark soil, about six inches. 